\title{
KONTRIBUSI SEKTOR PERTANIAN TERHADAP PEREKONOMIAN KABUPATEN BOLAANG MONGONDOW UTARA
}

\author{
AGRICULTURAL SECTOR'S CONTRIBUTION TO THE ECONOMY \\ IN NORTH BOLAANG MONGONDOW REGENCY
}

\author{
$\underline{\text { Findriani Lumikis }}^{(1)}$, Celcius Talumingan ${ }^{(2)}$, Sherly Gladys Jocom ${ }^{(2)}$
}

1) Mahasiswa Program Studi Agribisnis, Fakultas Pertanian, Universitas Sam Ratulangi, Manado

2) Dosen Program Studi Agribisnis, Fakultas Pertanian, Universitas Sam Ratulangi, Manado

*Penulis untuk korespondensi: findrianilumikis@gmail.com

Naskah diterima melalui Website Jurnal Ilmiah agrisosioekonomi@unsrat.ac.id

Rabu, 7 April 2021

Disetujui diterbitkan

Jumat, 28 Mei 2021

\begin{abstract}
The purpose of this study is to see the contribution of the agricultural sector to North Bolaang Mongondow Regency economy in a period of 8 years, namely 2010 to 2017, and to determine which agricultural sector and sub-sector is the base sector in Bolaang Mongondow Utara Regency. The data used is secondary data obtained from the Central Statistics Agency of North Bolaang Mongondow Regency and the Central Statistics Agency of North Sulawesi Province. The data analysis used are contribution formula, Location Quotient analysis and Dynamic Location Quotient method. The results of this study indicate that the agricultural, forestry and fisheries sectors are the largest contributors to the economy of North Bolaang Mongondow Regency from 2010 to 2017. The results of the Location Quotient analysis show that the agricultural, forestry and fisheries sectors are the basic sectors in North Bolaang Mongondow Regency. In addition, the sub-sector which is the base sector in North Bolaang Mongondow Regency is the forestry sub-sector. The food crops sub-sector, the annual horticulture sub-sector, and livestock and agricultural services are also the basic sectors in North Bolaang Mongondow Regency.
\end{abstract}

Keywords: contribution; leading sectors; agriculture; economy

\begin{abstract}
ABSTRAK
Tujuan dari penelitian ini adalah untuk melihat kontribusi sektor pertanian terhadap perekonomian Kabupaten Bolaang Mongondow Utara dalam kurun waktu 8 tahun yaitu tahun 2010 sampai 2017, dan untuk mengetahui sektor dan sub-sektor pertanian merupakan sektor basis di Kabupaten Bolaang Mongondow Utara. Data yang digunakan adalah data sekunder yang diperoleh dari Badan Pusat Statistik Kabupaten Bolaang Mongondow Utara dan Badan Pusat Statistik Provinsi Sulawesi Utara. Analisis data yang digunakan adalah rumus kontribusi, analisis Location Quotient dan metode Dynamic Location Quotient. Hasil penelitian ini menunjukkan bahwa sektor pertanian, kehutanan dan perikanan merupakan kontributor terbesar bagi perekonomian Kabupaten Bolaang Mongondow Utara dari tahun 2010 sampai tahun 2017. Hasil analisis Location Quotient menunjukkan bahwa sektor pertanian, kehutanan dan perikanan merupakan sektor basis di Kabupaten Bolaang Mongondow Utara. Selain itu sub-sektor yang merupakan sektor basis di Kabupaten Bolaang Mongondow Utara adalah sub-sektor kehutanan. Sub-sektor tanaman pangan, sub-sektor tanaman holtikultura tahunan, dan peternakan dan jasa pertanian juga merupakan sektor basis di Kabupaten Bolaang Mongondow Utara.
\end{abstract}

Kata Kunci: kontribusi; sektor unggulan; pertanian; ekonomi 


\section{PENDAHULUAN}

\section{Latar Belakang}

Indonesia dikenal sebagai negara agraris, yang mengandalkan sektor pertanian sebagai penopang pembangunan, di mana dalam sektor pertanian meliputi beberapa subsektor yaitu subsektor pertanian, peternakan dan jasa pertanian, subsektor tanaman pangan, subsektor tanaman holtikultura semusim, subsektor perkebunanan semusim, subsektor tanaman holtikultura tahunan, subsektor perkebunan tahunan, subsektor peternakan subsektor jasa pertanian dan perburuan, subsektor kehutanan dan penebangan kayu dan subsektor perikanan. Sektor pertanian merupakan sektor yang mempunyai peranan yang sangat penting dalam perekonomian indonesia, hal ini dikarenakan sektor pertanian berfungsi sebagai basis atau landasan pembangunan ekonomi.

Laju pertumbuhan ekonomi merupakan suatu indikator makro yang mengambarkan tingkat pertumbuhan ekonomi. Indikator ini biasanya digunakan untuk menilai seberapa jauh keberhasilan pembangunan suatu daerah dalam waktu tertentu. Proses lajunya pertumbuhan ekonomi suatu daerah ditunjukan dengan menggunakan tingkat pertambahan PDRB (Produk Domestik Regional Bruto), Pertumbuhan ekonomi sering diukur dengan menggunakan pertumbuhan Produk Domestik Bruto (PDRB). Produk Domestik Regional Bruto (PDRB) pada dasarnya merupakan jumlah nilai tambah yang dihasilkan oleh seluruh unit usaha dalam suatu daerah tertentu atau merupakan jumlah nilai barang dan jasa akhir yang dihasilkan oleh seluruh unit ekonomi (Fitria, 2013).

Kabupaten Bolaang Mongondow Utara merupakan salah satu dari 15 Kabupaten/kota di Provinsi Sulawesi Utara yang bergerak dalam bidang sektor pertanian. Berdasarkan UndangUndang No 10 Tahun 2007 Kabupaten Bolaang Mongondow Utara Merupakan Kabupaten hasil pemekaran dari kabupaten Bolaang Mongondow yang mempunyai enam kecamatan yaitu kecamataan Pinogaluman, Kecamatan Kaidipang, Kecamtan Bolangitang Barat,
Kecamatan Bolangitang Timur, Kecamatan Bintauna, kecamatan Sangkub dengan luas wilayah $1856.86 \mathrm{~km}^{2}$ dan jumlaah penduduk 78437 jiwa. Meskipun Kabupaten Bolaang Mongondow Utara menduduki peringkat ketujuh dengan penduduk miskin terbanyak namun kabupaten ini sudah memiliki banyak potensi ekonomi salah satunya sektor pertanian. sektor basis penting untuk diketahui karena pada pembangunan daerah yang mengutamakan pemberdayaan potensi daerah akan berjalan jika sektor basis daerah dapat optimalkan hal ini yang melatarbelakangi penelitian tentang kontribusi sektor pertanian terhadap perekonomian Kabupaten Bolaang Mongondow Utara.

\section{Pengertian Pembangunan Ekonomi}

Pembangunan ekonomi adalah suatu proses kenaikan pendapatan total dan pendapatan perkapita dengan memperhitungkan adanya pertumbuhan penduduk dan disertai dengan perubahan fundamental dalam struktur ekonomi suatu negara (Muhammad, 2009). Pembangunan ekonomi memiliki arti kandungan yang lebih luas dan dapat mencakup perubahan-perubahan pada tata susunan ekonomi masyarakat secara menyeluruh. Pembangunan merupakan proses transformasi yang dalam perjalanan waktu ditandai oleh perubahan struktural, yaitu perubahan pada landasan kegiatan ekonomi maupun pada kerangka susunan ekonomi masyarakat yang bersangkutan. Pembangunan ekonomi juga meliputi peningkatan produksi secara kuantatif yang mencakup proses perubahan pembangunan pada komposisi produksi.

$$
\text { Pembangunan ekonomi pada }
$$
hakekatnya bertujuan untuk meningkatkan kesejahteraan masyarakat dalam rangka meningkatkan kesejahteraan masyarakat maka diperlukan pertumbuhan ekonomi yang meningkat dan distribusi pendapatan yang lebih merata. Salah satu tujuan pembangunan ekonomi yang lain adalah menciptakan lapangan pekerjaan yang dibutuhkan oleh masyarakat, dengan demikian akan mengurangi pengangguran dan secara langsung dapat meningkatkan pendapatan nasional dan juga mendorong pertumbuhan ekonomi (Yesika dan $\mathrm{Ni}$ luh, 2015). 


\section{Teori Pertumbuhan Ekonomi}

Pertumbuhan ekonomi dapat di artikan juga sebagai proses kenaikan kapasitas pendapatan nasional. Pertumbuhan ekonomi dapat diartikan sebagai perkembangan kegiatan dalam perekonomian yang menyebabkan barang dan jasa yang diproduksi dalam masyarakat bertambah dan kemakmuran masyarakat meningkat (Anis dan Ardi, 2007). Menurut Putro (2010) Pertumbuhan ekonomi dapat diartikan sebagai perkembangan kegiatan perekonomian yang menyebabkan bertambahnya produksi barang dan jasa dan kemakmuran masyarakat yang meningkat. Menurut Sukirno dalam Yofi (2015), pertumbuhan ekonomi merupakan perkembangan kegiatan dalam perekonomian yang menyebabkan barang dan jasa yang diproduksi dalam masyarakat bertambah. Tingkat pertumbuhan ekonomi dapat diketahui dengan membandingkan pendapatan nasional berbagai tahun yang dihitung berdasarkan harga konstan.

\section{Teori Basis Ekonomi}

Dalam teori basis ekonomi (economic base), sebuah wilayah merupakan sebuah sistem sosio-ekonomi yang terpadu. Teori iniah yang mendasari pemikiran teknik Location Quontient (LQ), yaitu teknik yang membantu dalam menentukan kapasistas ekspor perekonomian daerah dan derajat keswasembadaan (selfsufficiency) suatu sektor. Sektor basis adalah kegiatan ekonomi yang tidak hanya mampu menyediakan bagi pasar dalam wilayah tetapi juga bagi pasar luar wilayah tersebut, sehingga permintaan barang dan tenaga kerja sektor ini bersifat eksogen. Sektor non basis adalah kegitan ekonomi yang hanya mampu menyediakan bagi pasar dalam wilayah sehingga permintaan barang, jasa, dan tenaga kerja terhadap sektor ini bersifat endogen (Januardy, 2013).

Menurut Taringan, (2005) Teori ekonomi basis mendasarkan pandangannya bahwa laju pertumbuhan ekonomi suatu wilayah ditentukan oleh besarnya peningkatan ekspor dari wilayah tersebut. Kegiatan ekonomi dikelompokan atas kegiatan basis dan nonbasis. Bertambah banyaknya sektor basis disuatu daerah akan menambah arus pendapatan kedalam daerah yang bersangkutan, menambah permintaan terhadap barang dan jasa didalamnya, meningkatkan nilai investasi dan menimbulkan kenaikan volume kegiatan bukan basis.
Menurut Taringan, (2005) Teori ekonomi basis mendasarkan pandangannya bahwa laju pertumbuhan ekonomi suatu wilayah ditentukan oleh besarnya peningkatan ekspor dari wilayah tersebut. Kegiatan ekonomi dikelompokan atas kegiatan basis dan nonbasis. Bertambah banyaknya sektor basis disuatu daerah akan menambah arus pendapatan kedalam daerah yang bersangkutan, menambah permintaan terhadap barang dan jasa didalamnya, meningkatkan nilai investasi dan menimbulkan kenaikan volume kegiatan bukan basis. Dengan demikian sesuai dengan namanya kegiatan basis mempunyai peran sebagai penggerak pertama dimana setiap perubahan mempunyai efek multiplier terhadap perekonomian agregat. Berdasarkan gagasan inilah, maka para ahli berpendapat bahwa sektor-sektor basis inilah yang seharusnya di kembangkan di suatu daerah.

\section{Rumusan Masalah}

1. Bagaimana kontribusi sektor pertanian tehadap perekonomian di Kabupaten Bolaang Mongondow Utara tahun 20102017?

2. Apakah Sektor pertanian dan subsektor pertanian merupakan sektor basis di Kabupaten Bolaang Mongondow Utara tahun 2010- 2017?

\section{Tujuan Penelitian}

1. Untuk melihat Kontribusi sektor pertanian terhadap perekonomian di Kabupaten Bolaang Mongondow Utara tahun 2010-2017.

2. Untuk mengetahui sektor pertanian dan subsektor pertanian merupakan sektor basis di Kabupaten Bolaang Mongondow Utara tahun 2010-2017

\section{Manfaat Penelitian}

Penelitian ini diharapkan dapat bermanfaat Bagi Pemerintah dan sebagai masukkan untuk menambah perekonomian wilayah khususnya di bidang sektor pertanian dimasa yang akan datang serta sebagai bahan referensi untuk penelitian selanjutnnya. 


\section{METODE PENELITIAN}

\section{Waktu dan Tempat Penelitian}

Penelitian ini dilaksanakan selama tiga bulan, mulai dari bulan Desember 2019 sampai bulan februari 2020 di Badan Pusat Statistik Kabupaten Bolaang Mongondow Utara dan Badan Pusat Statistik Provinsi Sulawesi Utara.

\section{Metode Pengumpulan Data}

Data yang digunakan dalam penelitian ini adalah data sekunder, dimana data sekunder yang diperoleh dari Badan Pusat Statistik Kabupaten Bolaang Mongondow Utara dan Badan Pusat Statistik Provinsi Sulawesi Utara.

\section{Metode Analisis Data}

Analisis data yang digunakan dalam penelitian ini adalah analisi:

1. Untuk melihat kontribusi sektor pertanian terhadap perekonomian Kabupaten bolaang Mongondow utara maka dalam penelitian ini di gunakan data PDRB ADHK tahun 2010 dengan rumus yaitu:

Kontribusi $(\%)=\frac{\text { Jumlah PDRB Sektor Pertanian Bolmut }}{\text { Jumlah PDRB Seluruh sektor Bolmut }} X 100 \%$

2. Untuk mengetahui apakah sektor pertanian dan subsektor pertanian merupakan sektor basis dalam perekonomian Kabupaten Bolaang Mongondow Utara maka digunakan Analisis Location Quontient (LQ):

$$
\mathrm{LQ}=\frac{\mathrm{l}_{1} / \mathrm{e}}{\mathrm{L}_{1} / \mathrm{E}}
$$

3. Untuk mengetahui posisi yang terjadi pada sektor pertanian dan sub sektor pertanian di Kabupaten Boalaang Mogondow Utara digunakan metode DLQ, dengan rumus sebagai berikut :

$$
\mathrm{DLQ}=\left\{\frac{(1+g i j) /(1+g j)^{t}}{(1+G i) /(1+G)}\right\}
$$

\section{HASIL DAN PEMBAHASAN}

\section{Keadaan Geografis Kabupaten Bolaang Mongondow Utara}

Kabupaten Bolaang Mongondow Utara merupakan salah satu daerah otonomi di Provinsi Sulawesi Utara yang secara geografis berada pada 6' Lintang Utara dan 11'Lintang Selatan dan antara 95'-141' Bujur Timur. Kabupaten Bolaang Mongondow Utara mempunyai batas- batas wilayah sebagai berikut
1. Sebelah utara berbatasan dengan laut Sulawesi

2. Sebelah timur berbatasan dengan Kecamatan Sang Tombolang (Kabupaten Bolaang Mongondow)

3. Sebelah Selatan berbatasan dengan Kecamatan Posigadon (Kabupaten Bolaang Mongondow Selatan)

4. Sebelah Barat berbatasan dengan Kecamatan Atinggola (Kabupaten Gorontalo Utara, Provinsi Gorontalo)

\section{Luas Wilayah}

Secara administrasi Kabupaten Bolaang Mongondow Utara mempunyai luas wilayah $1.856,86 \mathrm{~km}^{2}$.yang terdiri dari 6 kecamatan dan $107 \mathrm{des} /$ /kelurahan, luas daratan masing-masing kecamatan. Dapat dilihat dari Tabel 2 Kecamatan Sangkub memiliki luas wilayah terbesar dari seluruh kecamatan kecamatan yang ada di Kabupaten Bolaang Mongondow Utara yaitu seluas $567,85 \mathrm{~km}^{2}$ atau sekitar $30,58 \%$ dari total luas wilayah kabupaten ini, sedangkan kecamatan kaidipang memperoleh luas wilayah terkecil $85,09 \mathrm{~km}^{2}$ atau sekitar $4,58 \%$.

Tabel 1. Luas Wilayah Menurut Kecamatan di Kabupaten Bolaang Mongondow Utara Tahun

\begin{tabular}{|c|c|c|}
\hline Kecamatan & Luas $\left(\mathrm{Km}^{2}\right)$ & $\%$ \\
\hline (1) & (2) & (3) \\
\hline 1. Sangkub & 567,85 & 30,58 \\
\hline 2. Bintauna & 348,94 & 18,79 \\
\hline 3. Bolangitang Timur & 445,56 & 24,00 \\
\hline 4. Bolangitang Barat & 293,75 & 15,82 \\
\hline 5. Kaidipang & 85,09 & 4,58 \\
\hline 6. Pinogaluman & 115,59 & 6,23 \\
\hline $\begin{array}{c}\text { Bolaang Mongondow } \\
\text { Utara }\end{array}$ & 1856,86 & 100,00 \\
\hline
\end{tabular}
2017

\section{Kontribusi Sektor Pertanian}

Pada Tabel 2 dapat dilihat subsektor pertanian, peternakan, perburuan dan jasa pertanian mengalami penurunan dimana pada tahun 2010 memiliki nilai kontribusi 32,47\%, tahun $201131,32 \%$, tahun $201230,85 \%$, tahun $201330,30 \%$, tahun $201429,76 \%$, tahun 2015 $28,15 \%$, tahun $201628,50 \%$ dan terus menurun sampai pada tahun 2017 yang hanya $28,40 \%$ ini diakibatkan karena maraknya alih fungsi lahan pertanian kelahan non pertanian yang ada di Kabupaten Bolaang Mongondow Utara, sehingga membuat nilai kontribusi disektor ini 
menurun. Subsektor kehutanan dan penebangan kayu dan subsektor perikanan yang juga mengalami penurunan dimana subsektor kehutanan pada tahun 2010 memiiki niai kontribusi $12,72 \%$ dan menurun sampai pada tahun 2017 hanya hal ini disebabkan dari luas kawasan hutan produksi yang ada diKabupaten Bolaang Mongondow Utara. Sedangkan subsektor perikanan mengalami fluktuasi dimana pada tahun 2010 08,01\%, tahun $201108,31 \%$, tahun $201208,32 \%$, tahun $201308,52 \%$, tahun $201408,77 \%$, tahun $201508,5 \%$, tahun $201608,24 \%$ dan tahun 2017 08,10\% ini dikarenakan menurunya produksi perikanan tangkap yang ada di Kabupaten Bolaang Mongondow Utara.

Tabel 2. Nilai Kontribusi Sektor dan Subsektor Pertanian Kabupaten Bolang Mongonodow
Utara (Persen)

Dalam subsektor pertanian, petenakan, perburuan dan jasa pertanian terdapat beberapa subsektor diantaranya subsektor tanaman pangan yang mengalami penurunan dari tahun ke tahun di mana pada tahun 2010 memiiki niai kontribusi $14,41 \%$ dan terus menurun sampai pada tahun 2017 11,59\% hal ini karena berkurangya luas panen ubi kayu, kacang hijau dan ubi jalar yang ada di Kabupaten Bolaang Mongondow Utara. Berbeda dengan sub sektor tanaman pangan yang mengalami penurunan subsektor tanaman holtikutura tahunan menunjukkan peningkatan setiap tahunnya dimana pada tahun 2010 berkontribusi sebanyak 04,63\%, tahun 2011 $04,93 \%$, tahun $201205,19 \%$, tahun 2013 $05,42 \%$, tahun $201405,42 \%$, tahun 2015 $05,57 \%$, tahun $201605,57 \%$ dan terus meningkat sampai pada tahun 2017 dengan nilai $05,70 \%$ ha ini disebabkan meningkatnya produksi buah-buahan yang ada di Kabupaten ini. Berkurangnya luas kebun membuat subsektor perkebunan mengaami penuruan dimana pada tahun $201010,48 \%$ dan terus menurun sampai pada tahun 2017 08,09\% sedangkan subsektor peternakan mengaami peningkatan seama deapan tahun terakhir di mana pada tahun 2010 memiliki nilai kontribusi $02,03 \%$ dan terus meningkat sampai pada taun 2017 dengan nilai 05,15\% hal ini karena populasi ternak sapi potong, kambing, kuda, dan babi meningkat di Kabupaten Bolaang Mongondow Utara.

\section{Analisis Location Quotient (LQ)}

Berdasarkan Tabel 3, hasil anaisis Location Quotient sektor pertanian dari tahun 2010 sampai tahun 2017 memiliki nilai LQ lebih dari satu (LQ>1) ini berarti sektor pertanian di Kabuaten Bolaang Mongondow Utara dikategorikan sebagai sektor penunjang atau sektor yang mampu memenuhi kebutuan wilayah Kabupaten Bolaang Mongondow Utara, selain itu juga sudah mampu mengeksport keluar wilayah. Dalam sektor pertanian terdapat tiga subsekor yaitu subsektor pertanian, peternakan, perburuan dan jasa pertanian, kehutanan dan perikanan. Subsektor yang memiliki nilai LQ tertinggi atau LQ lebih dari satu (LQ>1) adalah subsektor kehutanan dan penebangan kayu dengan nilai LQ 7,77 pada tahun 2011 7,78, tahun 2012 8,00, tahun 2013 7,96, tahun 2014 7,93, tahun 2015 7,90, tahun 20167,86 dan sampai tahun 2017 memiliki nilai LQ 7,84 hal ini karena adanya dorongan subsektorsubsektor kehutanan dan penebangan kayu salah satunya masih luasnya hutan produksi yang ada di Kabupaten Bolaang Mongondow Utara. Sedangkan subsektor pertanian, peternakan, perburuan dan jasa pertanian serta sektor perikanan merupakan sektor nonbasis 
karena hanya memiliki nilai LQ kurang dari satu yang artinya tidak berpotensi eksport namun tidak menutup kemungkinan subsektor yang menjadi nonbasis menjadi basis mengingat keadaan wilayah Kabupaten Bolaang Mongondow Utara berada pada wilayah pesisir.

Tabel 3. Nilai Location Quotient (LQ) Sektor Pertanian dan Subsektor Pertanian Kabupaten Bolaang Mongondow Utara

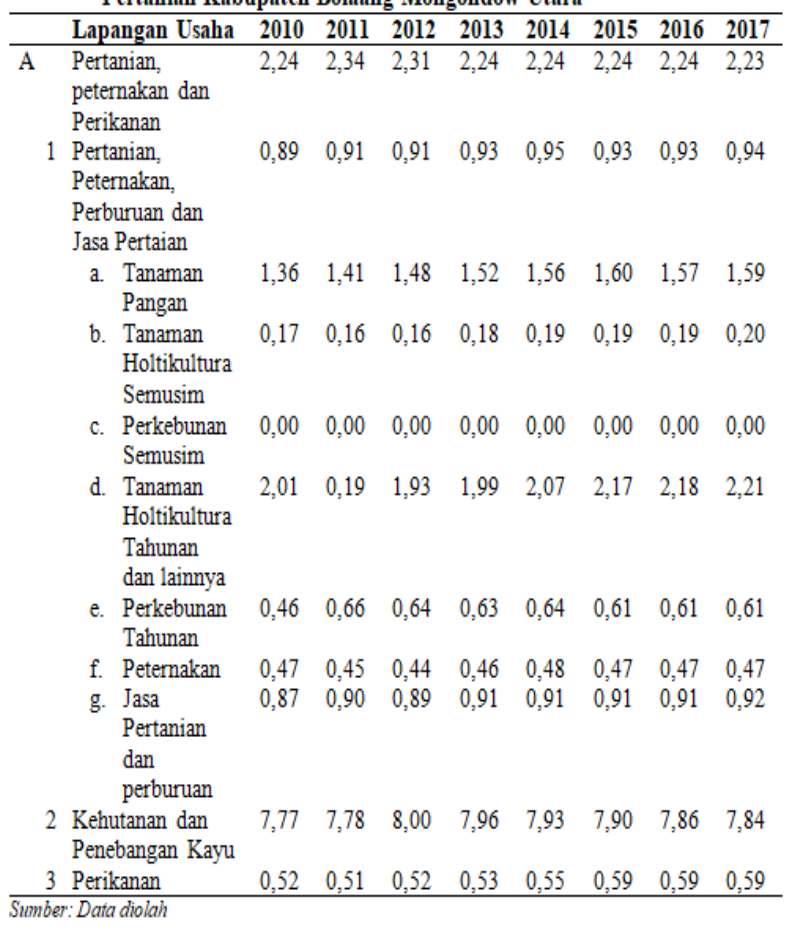

Di dalam subsektor pertanian, peternakan, perburuan dan jasa pertanian terdapat tujuh subsektor, dua subsektor diantaranya merupakan sektor basis di Kabupaten Bolaang Mongondow Utara, subsektor tanaman pangan memiliki nilai location quotient lebih dari satu dimana pada tahun 2010 1,36, tahun 2011 1,41, tahun 2012 1,48, tahun 20131,52 , tahun 20141,56 , tahun 2015 1,60, tahun 20161,57 dan tahun 2017 1,59 yang artinya berpotensi ekspor ini ditandai dengan masih luas panen yang ada diKabupaten ini, selain itu subsektor tanaman pangan juga sebagai penyedia bahan makanan pokok dan penyedia bahan makanan sehari- hari untuk masyarakat. Serta subsektor tanaman holtikutura tahunan lainnya yang juga memiliki nilai location quotient lebih dari satu dimana pada tahun 2010 mempunyai nilai LQ 2,01, tahun 2011 2,19, tahun 2012 1,93, tahun 2013 1,99, tahun 2014 2,07, tahun 2015 2,17, tahun
2016 2,18 dan tahun 2017 2,21 ini disebabkan karena memingkatnya produksi tanaman buahbuahan yang ada di Kabupaten Bolaang Mongondow Utara seingga membuat subsektor ini menjadi subsektor basis dan berpotensi ekspor.

\section{Dynamic Location Quontient}

Kelemahan metode Location Quotient (LQ) adalah hasilnya yang bersifat statis. Analisis Dynamic Location Quontient (DLQ) dilakukan untuk melengkapi analisis LQ karena Analisis Location Quotient tidak dapat digunakan untuk memperdiksi basis atau non basisnya suatu sektor pada masa yang akan datang, analisis DLQ merupakan perbandingan laju pertumbuhan sektor dan subsektor pertanian di Kabupaten dengan laju pertumbuhan sekor/subsektor yang sama ditingkat Provinsi. Analisis ini juga dapat digunaakan untuk mengetahui posisi dari sektor/subsektor basis menjadi sektor/subsektor non basis atau sebaliknya dari sektor/subsektor non basis menjadi sektor/subsektor basis dimasa mendatang.

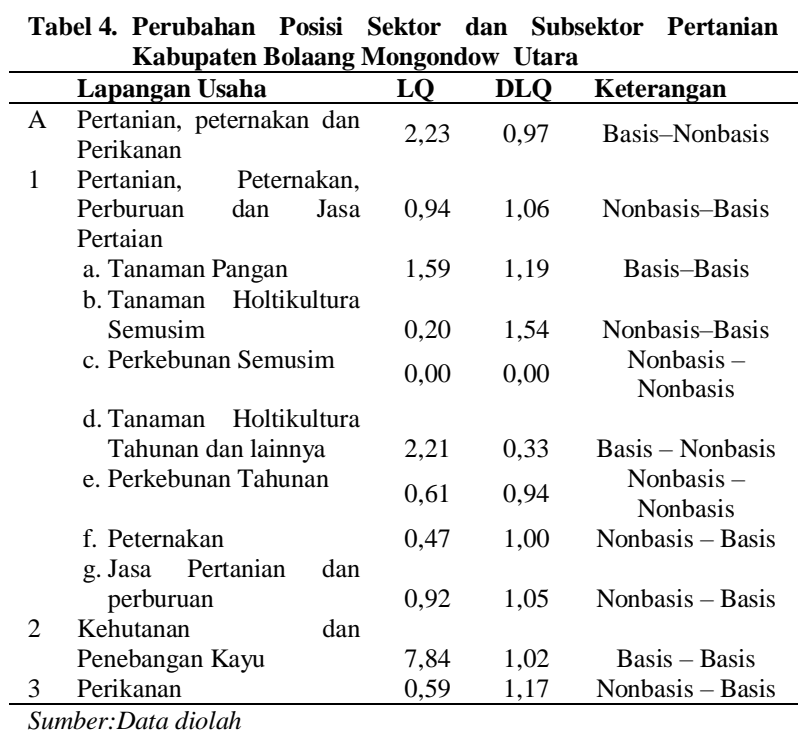

Pada Tabel 4 dapat dilihat bahwa sektor pertanian, peternakan dan perikanan mengalami perubahan di mana pada masa sekarang merupakan sektor basis namun berubah menjadi sektor nonbasis pada masa mendatang. Di sektor pertaniam, peternakan, dan perikanan terdapat tiga subsektor, satu subsektor menjadi subsektor basis di masa sekarang dan masa mendatang dan dua 
subsektor lainnya mengalami perubahan dari subsektor non basis menjadi basis dimasa mendatang.subsektor yang menjadi basis pada masa sekarang maupun masa mendatang adalah subsektor kehutanan dan penebangan kayu sedangkan subsektor pertaian, peternakan, perburuan dan jasa pertannian maupun subsektor perikanan merupakan subsektor yang mengalami perubahan dari subsektor non basis menjadi basis dimasa mendatang.

Dalam subsektor pertanian, peternakan, perburuan dan jasa pertanian terdapat tujuh subsektor. subsektor tanaman pangan merupakaan subsektor basis pada masa sekarang maupun masa mendatang. Subsekor yang mengalami perubahan dari sektor non basis menjadi basis di masa mendatang adalah subsektor tanaman holtikultura semusim, subsektor peternakan, dan subsektor jasa pertanian dan perburuan. Sedangkan Subsektor tanaman holtikultura tahunan merupkan subsektor basis di masa sekarang namun berubah menjadi subsektor nonbasis di masa mendatang, dan subsektor perkebunana semusim serta subsektor perkebunan tahunan yang tidak mengalami perubahan dimana pada masa sekarang maupun masa mendatang tetap menjadi sektor nonbasis.

\section{KESIMPULAN DAN SARAN}

\section{Kesimpulan}

Berdasarkan hasil penelitian dan pembahasan penelitian ini dapat disimpulkan sebagai berikut:

1. Sektor pertanian memiliki nilai kontribusi tertinggi dengan nilai rata-rata $48,84 \%$ dan sebagai penyumbang utama bagi perekonomian Kabupaten Bolaang Mongondow Utara begitu pun dengan subsektor pertanian, peternakan, perburuan dan jasa pertanian, subsektor kehutanan dan penebangan kayu yang juga masih memberikan kontribusi besar di kabupaten ini. Subsektor tanaman holtikultura tahunan dan subsektor peternakan yang terdapat dalam subsektor pertanian, peternakan, perburuan dan jasa pertanian yang mengalami peningkatan dimana subsektor tanaman holtikultura tahuhan memiliki nilai kontribusi dengan ratarata $05,03 \%$ dan subsektor peternakan yang juga mengalami peningktan dengan nilai ratarata $09,02 \%$ diKabupaten Bolaang Mongondow Utara.

2. Dari hasil analisis Location Quotient sektor pertanian, peternakan dan perikanan merupakan sektor basis atau memiliki LQ lebih dari satu yang artinya sektor pertanian, peternakan dan perikanan sudah mampu memenuhi kebutuhan wilahnya dan sudah mampu mengekspor keluar wilayah dikarenankan lahan pertanian yang masih luas serta banyaknya penduduk yang bekerja sebagai petani diKabupaten Bolaang Mongondow utara. Subsektor pertanian, peternakan dan perikanan yang merupakan sektor basis di Kabupaten Bolaang Mongondow Utara adalah subsektor kehutanan dan penebangan kayu ini karena masih luasnya hutan produksi diKabupaten ini, selain itu subsektor tanaman pangan dan tanaman holtikultura tahuanan yang terdapat dalam subsektor pertanian, peternakan dan perburuan dan jasa pertanian juga merupakan sektor basis atau subsektor yang memiliki nilai LQ lebih dari satu dan berpotensi ekspor.

\section{Saran \\ Pemerintah Kabupaten Bolaang} Mongondow Utara perlu memperhatikan kebijakan-kebijakan dalam sektor pertanian maupun subsektor pertanian dari sekarang, baik dari segi penyediaan lahan pertanian, bibit tanaman maupun tenaga kerja mengingat sektor pertanian di masa sekarang masih menjadi leading sektor di kabupaten ini.

\section{DAFTAR PUSTAKA}

Anis, S., Ardi, H. 2007. "Analisis Pengaruh PAD, DAU, DAK, dan Belanja Pembangunan Terhadap Pertumbuhan Ekonomi, Kemiskinan, dan Pengangguran Pendekatan Analisis Jalur". Jurnal. Fakultas Ekonomi Universitas Trunojoyo, Vol. 4, No. 2:211228.

Fitria, M.S. 2013. "Pengaruh Pertumbuhan Ekonomi Pendapatan Asli Daerah dan Dana Alokasi Umum Terhadap Pengalokasian Anggaran Belanja Modal (Studi Kasus Pada Kabupaten/Kota di Provinsi Jawa Barat)". 
Skripsi Fakultas Ekonomi Universitas Widyatama.

Januardy A.J Hidayat. 2013. "Analisis Struktur Perekonomian di Kota Manado". Jurnal.Fakultas Ekonomi Universitas Sam Ratulangi Manado.

Muhamad, N. R. S. 2009. "Aplikasi Location Quotient dan Shift Share Analysis Terhadap Peranan Sektor Pertanian di Kabupaten Bungo Provinsi Jambi". Skripsi. Fakultas Pertanian Universitas Sebelas Maret.

Putro, N.S. 2010. "Pengaruh Pertumbuhan Ekonomi Pendapatan Asli Daerah dan Dana Alokasi Umum Terhadap Pengalokasian Anggaran Belanja Modal (Studi Kasus Pada Kabupaten/Kota Provinsi Jawa Tengah)". Jurnal. Fakultas Ekonomi Universitas Diponegoro.
Taringan Robinson., 2005. "Ekonomi Regional Teori Dan Aplikasi "PT Bumi Aksara. Jakarta.

Yesika, R.B dan Ni Luh, K. 2015. "Pengaruh PAD Tenaga Kerja dan Investasi Terhadap Pertumbuhan Ekonomi di Provinsi Bali”. Jurnal. Fakultas Ekonomi dan Bisnis Universitas Udayana Bali.

Yofi, M.S. 2015. "Ananlisis Peran Sektor Pertanian Terhadap Pertumbuhan Ekonomi Kabupaten Banyuwangi Pendekatan Input-Output”. Skripsi. Fakultas Ekonomi Universitas Jember. 